\title{
Pembrolizumab as a treatment for PML?
}

\section{Waiting for Godot}

Renaud A. Du Pasquier, MD

Neurol Neuroimmunol Neuroinflamm 2019;6:e629. doi:10.1212/NXI.0000000000000629

Progressive multifocal leukoencephalopathy (PML) is an infrequent but severe disease of the brain. In the setting of immunosuppression, the polyomavirus JC (JCV) may reactivate, migrate to the brain, infect oligodendrocytes, and to a lesser extent astrocytes, and cause demyelinating lesions. As there are currently no available anti-JCV therapy, the only treatment consists of restoring immunity. Whereas restoring immunity is feasible in patients with AIDS-PML (by giving antiretroviral therapy) or in natalizumab-treated patients with MS (by stopping administration of natalizumab), achieving this in patients with hemopathies or with an intrinsically defective immune response is less straightforward. Consequently, the prognosis is particularly grim in the latter patients.

Initially designed to boost tumor cell-specific T-cell responses, anti-program cell death-1 (PD1) monoclonal antibodies (mAbs) have recently been proposed for the treatment of PML. ${ }^{1-3}$ Indeed, in a first wave of publications in the April issue of the NEJM, 10 patients with PML who received anti-PD-1 $\mathrm{mAb}$ were reported, including 7 who showed a mild to marked improvement, 1 who was stable before treatment, and 2 who had a frank worsening.

In the current issue of Neurolog $y^{\circledR}$ Neuroimmunology \& Neuroinflammation, 2 case reports showing absolutely no benefit of pembrolizumab mitigate this initial enthusiasm. ${ }^{4,5}$ The case reported by Küpper et al. is particularly intriguing since, a priori, if anyone should have been a good candidate for this drug, it was this patient. He had primary immunodeficiency syndrome, was young (42 years old), had never received immunosuppressive drugs, and, at the time of PML onset, had only a minor clinical deficit, limited MRI lesions, and a low viral load in his CSF. ${ }^{4} \mathrm{He}$ actually had the lowest number of JCV copies/mL (35) in the CSF of all 12 reported cases of PML treated with anti-PD-1 so far (table). Moreover, pembrolizumab was started early in the course of the disease, and the patient received 5 doses, whereas the majority of the other patients had received fewer doses. And yet, the patient showed a relentless evolution and fatal outcome. It seems that pembrolizumab may even have had a deleterious effect because the JCV viral load in the CSF began to rise after the beginning of pembrolizumab infusion (figure 1B of Ref. 4).

As with the 10 previously reported cases of PML treated with anti-PD-1, the 2 patients reported in this issue had a clear decrease in their PD-1+ T-cell number. Thus, one has to look for other parameters, which could predict the prognosis of PML in patients treated with anti-PD-1 mAbs. As highlighted in table, there is no obvious clinical or paraclinical characteristic that would predict the outcome of PML under pembrolizumab.

In this context, the second case report may provide some element of response. Pawlitzki et al. ${ }^{5}$ describe a 37-year-old patient who presented with several immunosuppressive conditions, developed PML, and received 2 infusions of pembrolizumab, but died 1 month after the second infusion. Unlike the first case, this second patient had an extremely high JCV viral load in the CSF $\left(>2.5 \times 10^{6}\right.$ copies $\left./ \mathrm{mL}\right)$ at the time of PML diagnosis, suggesting that JCV had already extensively infected the brain (table).

\author{
Correspondence \\ Dr. Du Pasquier \\ renaud.du-pasquier@chuv.ch
}

\section{RELATED ARTICLES}

\section{Clinical/Scientific} Notes

Ineffective treatment of PML with pembrolizumab: Exhausted memory T-cell subsets as a clue?

Page e627

\section{Clinical/Scientific Notes}

Pembrolizumab for progressive multifocal leukoencephalopathy due to primary immunodeficiency

Page e628 
Table Summary of the clinical and virologic data of the 12 patients with PML who have been treated with anti-program cell death-1

\begin{tabular}{|c|c|c|c|c|c|c|c|}
\hline No. & $\begin{array}{l}\text { Age/ } \\
\text { sex }\end{array}$ & Underlying condition & $\begin{array}{l}\text { No. of months between } \\
\text { progressive multifocal } \\
\text { leukoencephalopathy onset } \\
\text { and pembrolizumab } \\
\text { administration }\end{array}$ & $\begin{array}{l}\text { Viral load in CSF } \\
\text { at treatment } \\
\text { onset }(\mathrm{cps} / \mathrm{mL})\end{array}$ & $\begin{array}{l}\text { No. of doses of } \\
\text { pembrolizumab }\end{array}$ & Outcome & References \\
\hline 1 & $67 / M$ & $\begin{array}{l}\text { Chronic lymphocytic } \\
\text { leukemia }\end{array}$ & 15 & 232 & 3 & $=$ & Cortese et al. ${ }^{1}$ \\
\hline 2 & 78/M & $\begin{array}{l}\text { Chronic lymphocytic } \\
\text { leukemia }\end{array}$ & 7 & 6,044 & 2 & $(+)$ & Cortese et al. ${ }^{1}$ \\
\hline 3 & $48 / F$ & AIDS & 6 & 63 & 3 & + & Cortese et al. ${ }^{1}$ \\
\hline 4 & $69 / F$ & $\begin{array}{l}\text { Non-Hodgkin } \\
\text { lymphoma }\end{array}$ & 12 & 26,494 & 1 & - & Cortese et al. ${ }^{1}$ \\
\hline 5 & $31 / \mathrm{M}$ & Idiopathic lymphopenia & 2 & 5,248 & 3 & + & Cortese et al. ${ }^{1}$ \\
\hline 6 & $62 / F$ & $\begin{array}{l}\text { Idiopathic lymphopenia, } \\
\text { common variable } \\
\text { immunodeficiency, and } \\
\text { cyclic neutropenia }\end{array}$ & 3 & 28,350 & 2 & - & Cortese et al. ${ }^{1}$ \\
\hline 7 & 70/M & Hodgkin lymphoma & 2 & 261 & 1 & $(+)$ & Cortese et al. ${ }^{1}$ \\
\hline 8 & $58 / \mathrm{M}$ & AIDS & 12 & 286 & 3 & $(+)$ & Cortese et al. ${ }^{1}$ \\
\hline 9 & ?/M & $\begin{array}{l}\text { Variable } \\
\text { immunodeficiency and } \\
\text { B-cell lymphoma }\end{array}$ & 3 & 119,000 & 12 & + & Rauer et al. $^{2}$ \\
\hline $10^{a}$ & $60 / F$ & $\begin{array}{l}\text { Idiopathic primary } \\
\text { immunodeficiency }\end{array}$ & $\sim 3$ & 200,000 & $\geq 8$ & + & Walter et al. ${ }^{3}$ \\
\hline 11 & $42 / \mathrm{M}$ & $\begin{array}{l}\text { Primary } \\
\text { immunodeficiency }\end{array}$ & 5 & 38 & 5 & - & Küpper et al. ${ }^{4}$ \\
\hline 12 & $37 / M$ & $\begin{array}{l}\text { Combined } \\
\text { immunodeficiency and } \\
\text { Behçet disease }\end{array}$ & 1 & $2.5 \times 10^{6}$ & 2 & - & Pawlitzki et al..$^{5}$ \\
\hline
\end{tabular}

-, defavorable outcome under pembrolizumab; =, PML was already stabilized before pembrolizumab treatment; (+), mild improvement on pembrolizumab; + , marked improvement on pembrolizumab or nivolumab.

a This patient received nivolumab, not pembrolizumab.

In an attempt to understand the reasons why the patient did not respond to pembrolizumab, the authors analyzed the population of progenitor-exhausted vs terminally exhausted memory $\mathrm{T}$ cells. Of interest, they found that their patient had fewer progenitor- and more terminally exhausted $\mathrm{T}$ cells than another pembrolizumab-treated patient with PML who showed a favorable outcome. ${ }^{2}$ These data are interesting, as they suggest that only a subset of PD-1+ T cells has the capacity to revert from exhaustion and become active again. Thus, patients with PML who are deprived of progenitor-exhausted cells would be those who do not respond to pembrolizumab. As advocated by Koralnik in his NEJM editorial, ${ }^{6}$ the authors also looked at the JCV-specific T-cell response in the 2 patients, the one with a favorable outcome ${ }^{2}$ and the one with a progressive course of PML. ${ }^{5}$ They gather from this experiment that $\mathrm{JCV}$-specific $\mathrm{CD} 4^{+} \mathrm{T}$ cells might be more instrumental than $\mathrm{CD} 8^{+} \mathrm{T}$ ones in keeping JCV on check. However, considering the very low percentage of cells in both populations and the minimal differences between the responder and the progressive patient, these data should be taken with caution.

Finally, should we offer pembrolizumab to patients with PML or not? This drug is certainly not the long-awaited panacea for PML. However, considering the absence of treatment for this deadly disease, proposing this drug to patients for whom there is no other way to boost the cellular immune response seems, at least for the time being, reasonable.

\section{Study funding}

No targeted funding reported.

\section{Disclosure}

R.A. Du Pasquier served on the scientific advisory board for Merck, Celgene, and Sanofi; received travel funding and/or speaker honoraria from Celgene and Roche; and received research support from the Swiss National Foundation and Swiss Society for Multiple Sclerosis. Go to Neurology.org/ $\mathrm{NN}$ for full disclosures. 


\section{References}

1. Cortese I, Muranski P, Enose-Akahata Y, et al. Pembrolizumab treatment for progressive multifocal leukoencephalopathy. N Engl J Med 2019;380: 1597-1605.

2. Rauer S, Marks R, Urbach H, et al. Treatment of progressive multifocal leukoencephalopathy with pembrolizumab. N Engl J Med 2019;380:1676-1677.

3. Walter O, Treiner E, Bonneville F, et al; Immune Checkpoint Inhibitors in PML Study Group. Treatment of progressive multifocal Leukoencephalopathy with nivolumab. N Engl J Med 2019;380:1674-1676.
4. Küpper C, Heinrich J, Kamm K, Bücklein V, Rothenfusser S, Straube A, Pembrolizumab for progressive multifocal leukoencephalopathy due to primary immunodeficiency. Neurol Neuroimmunol Neuroinflamm 2019;6:e628. doi: 10.1212/NXI.0000000000000628.

5. Pawlitzki M, Schneider-Hohendorf T, Rolfes L, et al. Ineffective treatment of PML with pembrolizumab: exhausted memory T-cell subsets as a clue? Neurol Neuroimmunol Neuroinflamm 2019;6:e627. doi: 10.1212/NXI.0000000000000627.

6. Koralnik IJ. Can immune checkpoint inhibitors keep JC virus in check? N Engl J Med 2019;380:1667-1668. 


\section{Neurology \\ Neuroimmunology \& Neuroinflammation}

Pembrolizumab as a treatment for PML?: Waiting for Godot

Renaud A. Du Pasquier

Neurol Neuroimmunol Neuroinflamm 2019;6;e629

DOI 10.1212/NXI.0000000000000629

This information is current as of October 9, 2019

\section{Updated Information \& Services}

References

Citations

Subspecialty Collections

Permissions \& Licensing

Reprints including high resolution figures, can be found at:

http://nn.neurology.org/content/6/6/e629.full.html

This article cites 6 articles, 2 of which you can access for free at: http://nn.neurology.org/content/6/6/e629.full.html\#\#ref-list-1

This article has been cited by 1 HighWire-hosted articles: http://nn.neurology.org/content/6/6/e629.full.html\#\#otherarticles

This article, along with others on similar topics, appears in the following collection(s):

Autoimmune diseases

http://nn.neurology.org//cgi/collection/autoimmune_diseases Viral infections

http://nn.neurology.org//cgi/collection/viral_infections

Information about reproducing this article in parts (figures,tables) or in its entirety can be found online at:

http://nn.neurology.org/misc/about.xhtml\#permissions

Information about ordering reprints can be found online:

http://nn.neurology.org/misc/addir.xhtml\#reprintsus

Neurol Neuroimmunol Neuroinflamm is an official journal of the American Academy of Neurology.

Published since April 2014, it is an open-access, online-only, continuous publication journal. Copyright

Copyright () 2019 The Author(s). Published by Wolters Kluwer Health, Inc. on behalf of the American

Academy of Neurology.. All rights reserved. Online ISSN: 2332-7812.

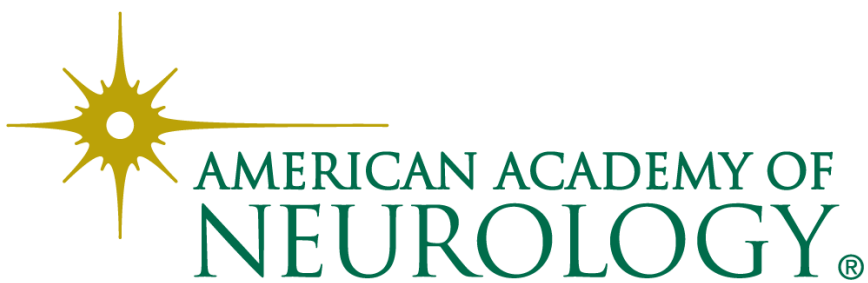

